\title{
Full Paper \\ Knowledge, ignorance and priorities for research in key areas of cancer survivorship: findings from a scoping review
}

\begin{abstract}
A Richardson*, , J Addington-Hall ', Z Amir², C Foster', D Stark ${ }^{3}$, J Armes ${ }^{4}$, SG Brearley ${ }^{5}$, L Hodges ${ }^{6}, \mathrm{~J} \mathrm{Hook}^{3}$, N Jarrett', Z Stamataki ${ }^{7}$, I Scott', J Walker ${ }^{6}$, L Ziegler ${ }^{8}$ and M Sharpe ${ }^{9}$

'Faculty of Health Sciences, University of Southampton, Building 67, Highfield, Southampton SOI7 IBJ, UK; ${ }^{2}$ School of Nursing, Midwifery and Social Work, University of Manchester, Jean McFarlane Building, Oxford Street, Manchester M 3 9PL, UK; ${ }^{3}$ St James' Institute of Oncology, Beckett Street, Leeds LS9 7TF, UK; ${ }^{4}$ Florence Nightingale School of Nursing \& Midwifery, King's College London, James Clerk Maxwell Building, 57 Waterloo Road, London SE I 8WA, UK; ${ }^{5}$ International Observatory on End of Life Care, Division of Health Research, School of Health and Medicine, University of Lancaster, Lancaster LAI 4YT, UK; ${ }^{6}$ Psychological Medicine Research, School of Molecular and Clinical Medicine, University of Edinburgh, Edinburgh EHIO 5HF, UK; ${ }^{7}$ The Christie NHS Foundation Trust, Wilmslow Road, Manchester M20 4BX, UK; ${ }^{8}$ Leeds Institute of Molecular Medicine, University of Leeds, St James University Hospital, Leeds LS9 7TF, UK; ${ }^{9}$ Psychological Medicine Research, Department of Psychiatry, University of Oxford, Warneford Hospital, Oxford OX3 7JX, UK
\end{abstract}

BACKGROUND: Patients who have completed initial cancer treatment (cancer survivors) have been relatively neglected. We need data to help us better understand the needs of this group and to underpin evidence-based service development.

METHODS: Scoping reviews of research published in the last two decades focussing on the problems faced by cancer survivors, and the effectiveness of interventions for these problems were undertaken. The aim was to identify what we know, what we do not know and opportunities where research could provide new information. We searched for, retrieved and rapidly appraised systematic reviews sourced from the most common electronic databases supplemented by more recently published individual studies.

RESULTS: The research evidence is surprisingly limited. We have some knowledge of the prevalence and nature of depression, pain and fatigue in cancer survivors. We know much less about cognitive and physical impairment, employment, financial well-being and relationships. Even where we have evidence, it is mostly of only moderate quality, is most often only for breast cancer and focuses almost exclusively on the early phase of survivorship. We have good evidence for the effectiveness of drug treatments for pain and moderate evidence for fatigue and depression, but not for other symptoms. Interventions based on rehabilitative and self-management approaches remain in the early stages of evaluation.

INTERPRETATION: There has been a substantial amount of research describing many of the problems experienced by the cancer survivors. This is strongest in the area of symptoms in the period soon after treatment. However, the quality of the evidence is often poor, and some topics have been little examined. We urgently need data on the natural evolution and scale of the problems of cancer survivors obtained from well-designed, large-scale cohort studies and the robust testing of interventions in clinical trials. Given the current financially constrained research funding environment, we suggest areas in which strategic investment might give findings that have the potential to make a major impact on patient well-being in a 5-year time scale.

British Journal of Cancer (20II) I 05, S82 - S94; doi:I0.1038/bjc.201 I.425 www.bjcancer.com

(c) 201। Cancer Research UK

Keywords: cancer survivors; scoping review; unmet needs; intervention; research priorities

As cancer incidence rises, cancer mortality falls and the population ages, the number of people living with and beyond cancer will continue to grow by more than 3\% a year (Maddams et al, 2009). Although this figure is a testament to advances in the early detection and better treatment of some cancers, there has been growing concern that the services required to meet the physical and emotional needs of survivors have not been adequately developed. A study from the US National Health Interview Study (Hewitt et al, 2003) comparing nearly 5000 cancer survivors with 90000 people without a history of cancer found that survivors were more likely to report being in poor health and have psychological or functional disability than those without a cancer diagnosis, and

*Correspondence: Professor A Richardson; E-mail: alison.richardson@ soton.ac.uk the likelihood of poor health was much higher among those who also had another comorbid condition in addition to their cancer. (Elliot and Corner, 2011).

In the UK and internationally, there have been calls for more detailed consideration to be given to the needs of cancer survivors alongside a desire to discover the most effective ways of meeting those needs (Hewitt et al, 2005; Cancer Journey Action Group of the Canadian Partnership Against Cancer, 2008; Department of Health, 2010). For example, in UK, the National Cancer Survivorship Initiative (NCSI) has called for a fundamental shift in the way cancer survivors are supported, moving from a formulaic medical emphasis in follow-up to an approach based on individualised needs and preferences and the promotion of recovery, health and well-being.

Research can have a central role in supporting such shifts, providing the evidence to build a picture of the range and extent of 
problems that cancer survivors face and testing approaches designed to prevent and alleviate those problems. The research reported here was commissioned to support the research work stream of the NCSI.

We aimed in this review to summarise what is known from existing research about the problems faced by cancer survivors and the effectiveness of different solutions to these problems. We also sought to identify areas in which research investment might have an impact on the care of cancer survivors within the next 5 years to inform the future research priorities of the NCSI. The term 'cancer survivor' has been widely interpreted; we have taken this to mean someone who has completed initial cancer treatment and has no evidence of active disease, or is living with progressive disease but is not in the terminal phase of their illness or has had cancer in the past (Macmillan Cancer Support, 2008). We concentrated on the stages of the cancer journey covered by: (1) the period immediately following treatment and (2) the shortand long-term consequences of cancer. Owing to the breadth of the topic area, we used scoping review methodologies. Through the application of this method, we sought to identify what we know, what we do not know and opportunities for research to improve our knowledge of cancer survivorship.

\section{MATERIALS AND METHODS}

Scoping reviews 'aim to map rapidly the key concepts underpinning a research area and the main sources and types of evidence available... [suitable for] .... an area is complex or has not been reviewed comprehensively before' (Arksey and O' Malley, 2005). They are often used to gain a preliminary assessment of potentially relevant literature and its size. Our methods broadly followed those of Arksey and O' Malley (2005). Two separate but linked reviews focussed on (1) problems faced by cancer survivors and (2) the effectiveness of interventions for these problems. In order to make the task manageable in the time available, we searched for, retrieved and rapidly appraised systematic reviews (rather than original publications) sourced from the most common electronic databases (including Medline, EMBASE, Psychlit, PsychINFO, Cochrane Library, CINAHL, Web of Science and British Nursing Index) up to the end of 2009. The reviews were supplemented with more recently published individual studies. Detailed explanations of the methods used can be found elsewhere (Foster et al, 2009; Richardson et al, 2009; Ziegler et al, 2009; Brearley et al, 2011).

\section{Review one}

The first review focussed on the descriptions of the "health and well-being' of cancer survivors including physical, psychological, social and practical aspects.

Inclusion and exclusion criteria Reviews (including systematic, comprehensive or other types of literature reviews of research evidence of both qualitative and/or quantitative studies) were included if they were written in English, published between 1 January 2000 and 31 December 2009 and focussed on health and well-being in the acute, sub-acute, long-term and diseasefree phases of cancer survivorship. Reviews related to childhood and adolescent cancer were excluded (as they were subject to a different piece of work), as were drug trials and review articles other than research literature reviews (e.g., retrospective data review; overview; review of treatment outcome; review of an individual patient case).

\section{Review two}

The second scoping review was targeted at scoping and collating research evidence on the effectiveness of solutions to the problems cancer survivors faced. Therefore, the focus of this review was on retrieving systematic reviews and randomised controlled trials (RCTs) of interventions for common problems including symptoms of depression, anxiety and fear of recurrence, emotional distress, fatigue and pain and impairments to physical functioning, social functioning (including relationships), work and employment and cognitive functioning.

Inclusion and exclusion criteria Published reviews were included if they were written in the English language, published between 1990 and the end of 2009, included an intervention that had relief of one of the above as its primary aim and conducted using systematic review methods. The searching extended to both pharmacological- and non-pharmacological-type interventions and professional-delivered and self-help-type interventions. We excluded reviews devoted to childhood and adolescent cancer and review articles other than those of randomised controlled trials.

\section{Procedures}

Abstracts and titles of review articles considered potentially relevant were selected for further examination. The bibliographic details, keywords, abstracts, website address (where available) of identified articles were imported into bibliographic databases. Relevant reviews were selected for synthesis with reference to inclusion/exclusion criteria.

Data were extracted and summarised using data extraction sheets suitable to the different types of reviews. Each review identified for possible inclusion in the problems in the health and well-being element of the scoping review was awarded a quality score (out of 7) as a broad indication of quality. A review was included if it achieved a score of $\geqslant 2$. Assessment of the quality of reviews in review 1 was informed by the checklists advocated by the CASP-UK (2011) and Centre for Reviews and Dissemination (2008). Almost all the reviews in the solutions scoping review were high-quality Cochrane-type reviews, and quality screening was not undertaken. Judgments about the study quality of the individual studies included in the reviews were drawn from the commentary available in the systematic reviews. This constitutes a broad assessment of this feature of the research and relies on what we could infer from comments made by the original review authors. Consequently, we only provide a very broad and general indication of whether the quality of the research evidence in relation to each topic was low, medium or high. In terms of the quantity of research contained in the reviews, this could not always be precisely determined, as sometimes review authors (especially in relation to the health and well-being review) did not state explicitly the number of studies they reviewed, but referenced studies throughout the text. Because there was scope for error in counting these, we chose to use approximations and applied a banding system (low, moderate and high amounts of research), and therefore a precise number of studies are not offered (see Table 1 for a summary of criteria used).

To supplement the search for reviews, additional searches to identify primary research papers published after the time frame of the included reviews were performed. This was an extremely timelimited exercise, and we adopted a simple and pragmatic method of focussing on high-quality publications whereby we only included those studies published in journals with an impact factor of more $>3$ for studies of health and well-being and $>5$ for studies of interventions.

\section{RESULTS}

We included 25 reviews and 61 primary research papers describing problems of health and well-being in review 1, and 49 reviews and 21 primary research papers with respect to solutions in review 2. 

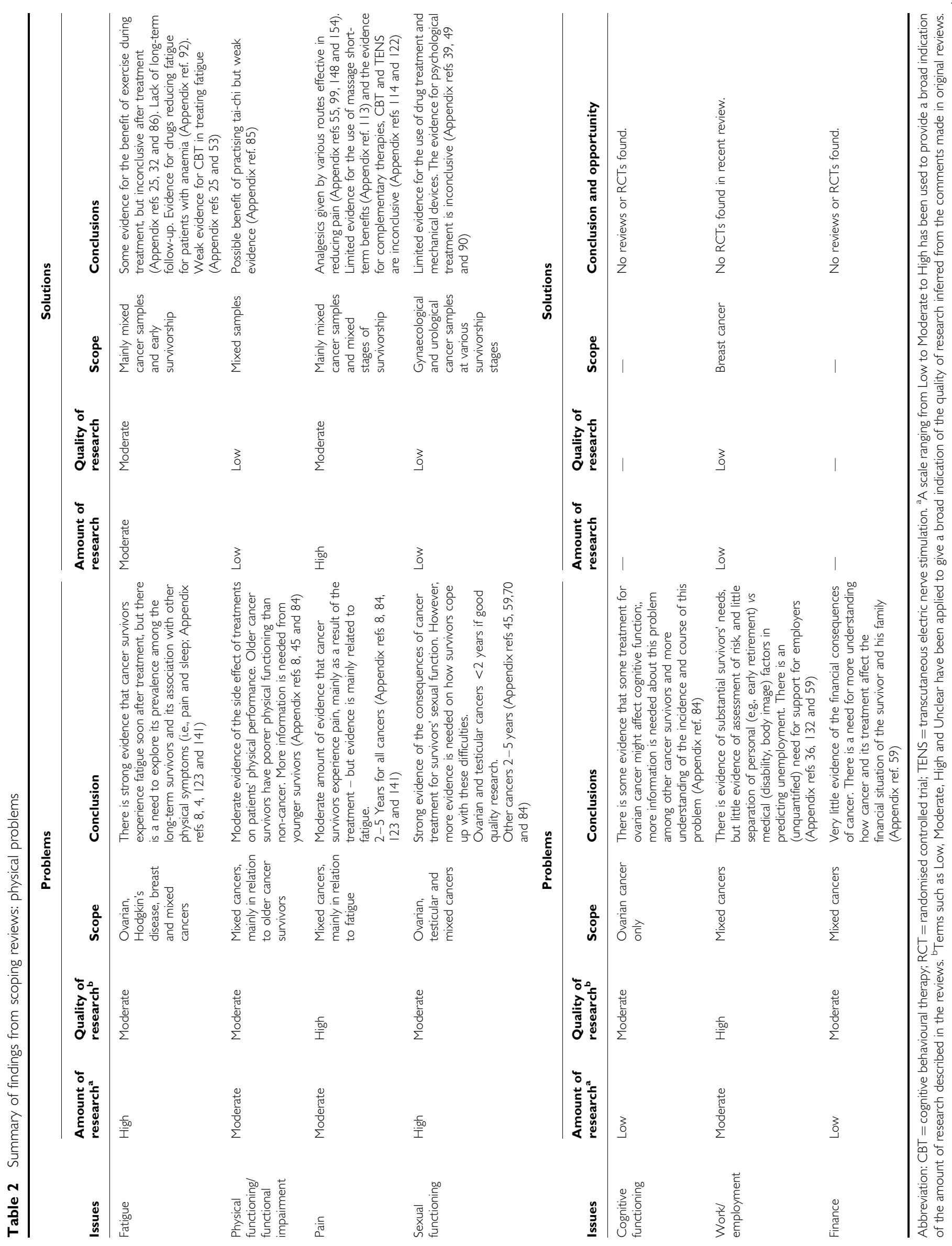


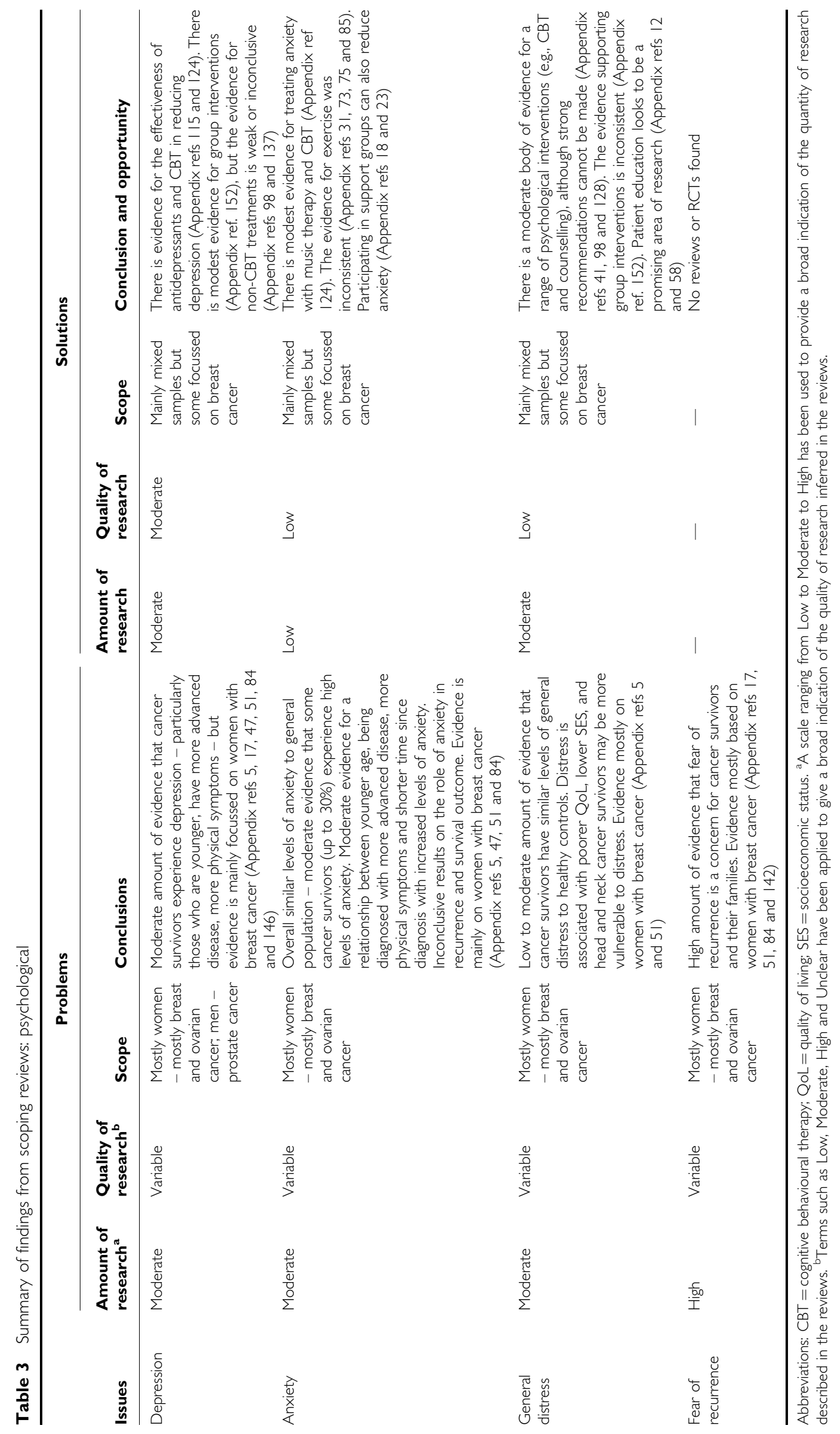




\section{Depression}

The problem There is good evidence for a significantly increased rate of depression in cancer survivors during and soon after active treatment. However, there is less evidence concerning long-term survivors; persistent and recurrent depression is likely to be a problem for an important minority. Those most at risk are people who are younger, female and who have more advanced disease. Much of the evidence is limited to women with breast cancer.

Solutions There is good evidence that antidepressant drugs, CBT and complex treatment models such as collaborative care are effective for depression in the general population. However, there is only moderately good evidence that antidepressants, CBT and collaborative care are effective in reducing depression specifically in cancer survivors. We do not know how best to identify depression in long-term survivors.

\section{Anxiety}

The problem There is some evidence for increased anxiety after treatment; this is connected with anxiety about check-ups and medical follow-up appointments. There is little evidence concerning long-term survivors, but anxiety, especially about recurrence, is a problem for a proportion. Those most at risk are younger, have more physical symptoms, are closer to point of diagnosis and have more advanced disease. Most of the evidence is limited to women, particularly those with breast and ovarian cancer.

Solutions There is limited evidence about effective interventions for anxiety. Cognitive behavioural therapy is likely to help, but has not been adequately evaluated. Aromatherapy massage may bring some short-term relief. Exercise may also have a role.

\section{Social needs}

The problem The social impact of cancer and the influence of social support on outcomes such as emotional well-being and quality of life have been studied mainly in breast cancer. There is modest evidence that perceived social support is positively associated with well-being and quality of life. The psychosocial implications of cancer survivorship for family members have not been well studied. Evidence to date suggests that distress in family members persists over 5 years following diagnosis.

Solutions There is modest evidence that support groups have a positive effect on marital satisfaction and sexual relationships, and some evidence that interventions targeted at spouses might improve marital relationships. No other clear recommendations can be made about approaches that might prove effective with respect to meeting social need.

\section{Quality of the primary research}

Although a scoping review does not offer a detailed critique of the methods adopted or study quality, through the process of conducting our review we were struck by a number of recurrent methodological problems that were frequently highlighted by those conducting systematic reviews. These shortcomings are as follows: 
Research questions A key and all too common problem is the lack of precision in the research questions that are asked (e.g., the effect of a vaguely specified intervention on a wide range of vaguely specified outcomes). Such studies, not surprisingly, produce only vague answers.

Samples studied The origin of samples is sometimes poorly described and they are often not representative of the population studied. Most research has been carried out on women with breast cancer; other cancers have been neglected. There is little research into the needs of minority groups and certain cancers, such as lung and the less common cancers. Most study samples are simply too small to give robust results.

Measures A wide variety of measures have been used, with little consistency between studies, making the combination of data across studies problematic.

Study design A common criticism is that studies are methodologically weak and subject to multiple sources of bias, which may make results unreliable. Another major problem of design is the lack of long-term follow-up, both in studies of need and of interventions.
Interventions The interventions evaluated have often been poorly characterised and may not be of a form that could realistically be implemented in practice.

\section{Interpretation}

The research evidence is surprisingly limited. We have some knowledge of the prevalence and nature of depression, pain and fatigue in cancer survivors. We know much less about cognitive and physical impairment, employment, financial well-being and relationships. Even where we have evidence, it is mostly of only moderate quality, is most often focussed on breast cancer and almost exclusively on the early phase of survivorship. We have good evidence of the effectiveness of treatments for pain, and moderate evidence for fatigue and depression, but not for other symptoms. Interventions based on rehabilitative and self-management approaches remain in the early stages of evaluation. Our lack of knowledge about how to address the problems of cancer survivors is compounded by a lack of research into how to implement interventions as part of routinely offered programmes of care. We certainly need more research if we are to address the problems of cancer survivors more effectively.

Table 5 Future 'best buys' for research investment in key areas of cancer survivorship

\begin{tabular}{|c|c|c|c|}
\hline \multirow[b]{2}{*}{ Issue } & \multicolumn{3}{|l|}{ Time frame } \\
\hline & Less than 2 years & 2-5 Years & 5 Years plus \\
\hline $\begin{array}{l}\text { Fatigue and } \\
\text { physical function }\end{array}$ & $\begin{array}{l}\text { (I) Pilot studies of simple, feasible methods of } \\
\text { identifying fatigue in survivors; (2) studies of barriers to } \\
\text { implementing treatments such as guided self-help, } \\
\text { telephone delivered treatment based on CBT principles } \\
\text { and exercise }\end{array}$ & $\begin{array}{l}\text { Large, multi-centre studies of fatigue } \\
\text { management with adequate follow-up } \\
\text { period that integrates screening and } \\
\text { treatment }\end{array}$ & $\begin{array}{l}\text { Prospective cohort studies with age-matched } \\
\text { comparisons to study course of fatigue and } \\
\text { physical function in relation to factors such as } \\
\text { cancer site, treatment history and stage }\end{array}$ \\
\hline Pain & $\begin{array}{l}\text { (I) Secondary analysis of existing data on prevalence of } \\
\text { pain and risk factors in survivors; (2) pilot studies of simple } \\
\text { and feasible methods of identifying pain in survivors; } \\
\text { (3) studies of the barriers to implementing pain } \\
\text { management models such as collaborative care }\end{array}$ & $\begin{array}{l}\text { Large trials of interventions based on } \\
\text { feasible models of delivery that integrate } \\
\text { screening and treatment systems such as } \\
\text { collaborative care }\end{array}$ & $\begin{array}{l}\text { Cohort study to identify risk factors for long- } \\
\text { term pain }\end{array}$ \\
\hline Sexual function & $\begin{array}{l}\text { Surveys of prevalence and psychological and social } \\
\text { associations }\end{array}$ & $\begin{array}{l}\text { Feasibility studies of integrated systems of } \\
\text { assessment and management }\end{array}$ & Large trials of interventions \\
\hline $\begin{array}{l}\text { Cognitive } \\
\text { function }\end{array}$ & $\begin{array}{l}\text { Prevalence and risk factor studies of cognitive impairment } \\
\text { and its association with functional and psychosocial ability }\end{array}$ & $\begin{array}{l}\text { Pilot studies of methods to identify and } \\
\text { intervene with those who are suffering } \\
\text { from cognitive impairment }\end{array}$ & $\begin{array}{l}\text { Large trials of preventative and treatment } \\
\text { interventions }\end{array}$ \\
\hline $\begin{array}{l}\text { Employment, } \\
\text { finance and } \\
\text { return to work }\end{array}$ & $\begin{array}{l}\text { (I) Theoretical and modelling work to establish the } \\
\text { transferability of vocational rehabilitation approaches used } \\
\text { in other contexts to cancer survivorship; (2) In-depth } \\
\text { studies to understand the financial effects of cancer; } \\
\text { (3) Studies to evaluate the best way to educate and } \\
\text { support employers to support cancer survivors whilst } \\
\text { returning to work }\end{array}$ & $\begin{array}{l}\text { Well-designed pilot trials of feasible } \\
\text { methods of intervention }\end{array}$ & $\begin{array}{l}\text { Large, prospective cohort studies to identify } \\
\text { factors that impact on return to work and } \\
\text { vulnerable subgroups and large-scale } \\
\text { intervention studies }\end{array}$ \\
\hline $\begin{array}{l}\text { Emotional } \\
\text { distress }\end{array}$ & $\begin{array}{l}\text { (I) Secondary analysis of existing data on long-term } \\
\text { outcome; (2) Well-designed pilot trials of feasible methods } \\
\text { of intervention }\end{array}$ & $\begin{array}{l}\text { Large trials of interventions based on } \\
\text { patient education including guided self- } \\
\text { help and telephone delivered treatment } \\
\text { based on CBT principles }\end{array}$ & $\begin{array}{l}\text { ( I) Large, prospective cohort studies of mixed } \\
\text { cancer groups; (2) Studies to improve } \\
\text { understanding, identification and management } \\
\text { of distress in men and BME groups }\end{array}$ \\
\hline Depression & $\begin{array}{l}\text { (I) Secondary analysis of existing data on prevalence and } \\
\text { risk factors in long-term survivors; (2) -pilot studies of } \\
\text { simple feasible methods of identifying depression in } \\
\text { survivors in hospital and primary care; (3) Studies of the } \\
\text { barriers to implementing established treatment models } \\
\text { such as collaborative care }\end{array}$ & $\begin{array}{l}\text { Large trials of interventions based on } \\
\text { feasible models of delivery that integrate } \\
\text { screening and treatment systems and have } \\
\text { an emphasis on primary care provision } \\
\text { such as collaborative care }\end{array}$ & $\begin{array}{l}\text { Studies to improve understanding of how we } \\
\text { can identify and manage depression in men } \\
\text { and BME }\end{array}$ \\
\hline Anxiety & $\begin{array}{l}\text { Secondary analysis of existing data to determine prevalence } \\
\text { of anxiety in the long-term and associations with fear of } \\
\text { recurrence }\end{array}$ & $\begin{array}{l}\text { Well-designed pilot trials of feasible } \\
\text { methods that combine detection and } \\
\text { intervention suitable to address minor, } \\
\text { modest and severe anxiety and } \\
\text { interventions for fear of recurrence }\end{array}$ & $\begin{array}{l}\text { ( I) Large-scale, multi-centre trials of simple } \\
\text { feasible interventions; ( } 2 \text { ) Cohort study to } \\
\text { identify risk factors for persistent anxiety }\end{array}$ \\
\hline Social needs & $\begin{array}{l}\text { (I) Exploratory studies to identify forms of social support } \\
\text { that might prove effective and factors that dictate whether } \\
\text { families do or do not seek support; (2) Secondary analysis } \\
\text { of existing data on long-term outcome and moderating } \\
\text { factors }\end{array}$ & $\begin{array}{l}\text { ( I) Pilot trials of feasible methods of } \\
\text { intervention to minimise or manage the } \\
\text { effect of cancer on relationships; } \\
\text { (2) Studies of the effect of a diagnose if } \\
\text { cancer on relationships }\end{array}$ & $\begin{array}{l}\text { Cohort studies of mixed cancer groups that } \\
\text { include family members. More understanding } \\
\text { of how to identify and manage those who } \\
\text { perceive they have unmet need, especially in } \\
\text { those with cancers other than breast cancer } \\
\text { and in BME and other disadvantaged groups }\end{array}$ \\
\hline
\end{tabular}

Abbreviations: $\mathrm{CBT}=$ cognitive behavioural therapy; $\mathrm{BME}=$ black and minority ethnic groups. 


\section{Limitations of the review}

Our review of this large area of research is necessarily limited in scope by the time and resources available to complete it. Primarily, reviews of studies rather than original research reports were examined. Where we did search for individual studies after the publication date of the most recent reviews, we confined this exercise to journals that had a particular impact factor. This may have impacted our findings, particularly judgments about the amount of research available in relation to an individual topic, as some of the journals that publish studies in this field (e.g., Supportive Cancer Care, Cancer Nursing and European Journal of Cancer Care) had not achieved the impact factor selected to merit inclusion. There was a focus on the more common problems and widely used treatments for them to the neglect of other topics. For example, we did not address the organisation and delivery of care, information and support (e.g., the process of care planning and methods of care delivery), the impact on families and the lifestyle dimensions of survivorship.

\section{Setting priorities for future research}

Identifying research priorities is not as simple as it might first appear. Critically, it is not as simple as identifying the 'gaps' in the evidence described above. The presence of 'gaps' in evidence may indicate an area difficult to research that would need many years of investment to address. Furthermore, even in areas where we have the information we need about a problem, including possible solutions, research may still be needed to work out how to implement these solutions in everyday practice.

It is also important to note that research takes more than money; although money is essential, it also requires skilled researchers with an interest in the question to deliver high-quality answers. Such people remain in very short supply for many of the questions posed here, despite this being recognised some years ago (National Cancer Research Institute, 2004).

Scoping reviews, especially those designed to identify research gaps, are often enhanced, and results can be made more useful if policymakers, clinicians and service users contribute to the work in the form of consultation (Arksey and O' Malley, 2005). Our study also included a consultation and prioritisation element (details can be found in (Armes et al, 2009)). Contributors to this exercise included researchers, commissioners and consumers of survivorship research in the UK. The top five priorities to emerge from a survey and consensus event included: studies to understand the epidemiology of needs; methods to identify and manage consequences of cancer and treatment; the organisation and delivery of care; psychosocial issues; and informal carers and families (Armes et al, 2009). The consultation served to inform and, in some cases, validate the findings from the scoping review. For example, the strong desire for research to determine optimum ways to organise and deliver services emerged in this way.

The shrewd investor in research might therefore be well advised to fund areas of research where not only are there 'gaps' in evidence about important topics but where there is also a likelihood of the findings being 'implementation ready' in a reasonable time scale and for which there are existing groups with a track record of delivering high-quality research. These represent what we refer to as 'best buys' for research investment and are collated in Table 5. We use periods of less than 2 years (very short term), 2-5 years (medium term) and greater than 5 years to qualify these recommendations. These take into account the stage the research has reached, and the relative complexity, scale and length of time it might take to undertake it. We would suggest that funders do not spend limited funds on yet more small-scale research studies unless these comprise a development phase of more significant, large-scale research. Rather, we need wellfunded, coordinated research efforts executed by skilled research teams working in partnership with clinicians and cancer survivors. Priorities should be (1) large-scale prospective cohort studies that sufficiently describe needs of long-term survivors and to predict those most at risk; (2) robust randomised trials of well-specified 'delivery ready' interventions; (3) research to determine the most effective and efficient ways to organise care.

\section{ACKNOWLEDGEMENTS}

We thank the COMPASS and CECo administrators, Susie Edwards and Anne-Marie McDonnell, for their support during the conduct of the study and Liz Neilly and Linda Robertson, librarians at the University of Leeds and University of Southampton, respectively. We also thank those who contributed to the survey and consensus event about research priorities and Jim Elliott and John Neate, Joint Leads of the National Cancer Survivorship Initiative research work stream, for their guidance. The research upon which this paper is based was funded by Macmillan Cancer Support on behalf of the Department of Health and the National Cancer Survivorship Initiative. The views expressed here are those of the authors and not necessarily those of Macmillan Cancer Support or the Department of Health.

\section{REFERENCES}

Arksey H, O’ Malley L (2005) Scoping studies: towards a methodological framework. Int J Social Res Methodol 8: 19-32

Armes J, Richardson A, Addington-Hall J (2009) Report on National Cancer Survivorship Consultation on Research Priorities. Technical Report. King's College London and University of Southampton: London

Brearley S, Stamataki Z, Addington-Hall J, Foster C, Hodges L, Jarrett N, Richardson A, Scott I, Sharpe M, Stark D, Siller C, Ziegler L, Amir Z (2011) The physical and practical problems experienced by cancer survivors: a rapid review and synthesis of the literature. Eur J Oncol Nurs 15(3): $199-288$

Cancer Journey Action Group of the Canadian Partnership Against Cancer (2008) Canadian invitational cancer survivorship workshop: creating an agenda for cancer survivorship March 25-26, 2008 Toronto, Ontario

CASP-UK (2011) Critical skills appraisal programme: making sense of evidence. Accessed at www.casp-uk.net/casp-downloads/checklists/. 15 August 2011

Centre for Reviews and Dissemination (2008) Systematic Reviews: CRD's Guidance for Undertaking Reviews in Health Care. CRD, University of York: York
Department of Health, Macmillan Cancer Support, NHS Improvement (2010) National Cancer Survivorship Initiative Vision. Department of Health: London

Elliot J, Fallows A, Staetsky L, Smith PWF, Foster CL, Maher EJ, Corner J (2011) The health and well-being of cancer survivors in the UK: findings from a population-based survey. Br J Cancer 105(Suppl 1): S11-S20

Foster C, Amir Z, Jarrett N, Stamataki Z, Brearley S, Scott I (2009) Scoping of Research Evidence Regarding the Health and Well-Being of Cancer Survivors: Psychological and Social Problems Faced by Cancer Survivors, and their Physical and Practical Well-Being. Technical Report. University of Southampton and University of Manchester: UK

Hewitt M, Greenfield S, Stovall E (eds) (2005) From Cancer Patient to Cancer Survivor. Lost in Transition. The National Academies Press: Washington DC

Hewitt M, Rowland J, Yancik R (2003) Cancer survivors in the United States. J Gerontol 58(1): $82-91$

Macmillan Cancer Support (2008) Two Million Reasons. The Cancer Survivorship Agenda. Macmillan Cancer Support: London

Maddams J, Brewster D, Gavin A, Steward J, Elliot J, Utley M, Moller H (2009) Cancer prevalence in the United Kingdom: estimates for 2008. Br J Cancer 101: $541-547$ 
National Cancer Research Institute (2004) Supportive and Palliative Care Research in the UK. Report of the NCRI Strategic Planning Group on Supportive and Palliative Care. National Cancer Research Institute: London

Richardson A, Addington-Hall J, Stark D, Foster C, Amir Z, Sharpe M (2009) Determining Research Priorities for Cancer Survivorship: Consultation and Evidence Review. COMPASS and CECO National Cancer Research Institute supportive and palliative care collaboratives: UK

Ziegler L, Hook J, Stark D, Neilly L, Hodges L, Walker J, Sharpe M (2009) Systematic Scope and Collation of Research Evidence Regarding Interventions. Technical Report. University of Leeds and University of Edinburgh: UK

\section{Appendix}

\section{Bibliography}

1 Absolom K, Eiser C, Turner L, Ledger W, Ross R, Davies H, Coleman R, Hancock B, Snowden J, Greenfield D (2008) Ovarian failure following cancer treatment: current management and quality of life. Hum Reprod 23(11): 2506-2512

2 Ahmed RL, Prizment A, Lazovich D, Schmitz KH, Folsom AR (2008) Lymphedema and quality of life in breast cancer survivors: the Iowa Women's Health Study. J Clin Oncol 26(35): $5689-5696$

3 Allareddy V, Kennedy J, West MM, Konety BR (2006) Quality of life in long-term survivors of bladder cancer. Cancer 106(11): $2355-2362$

4 Allen JD, Savadatti S, Levy AG (2009) The transition from breast cancer 'patient' to 'survivor. Psychooncology 18: 71-78

5 Arden-Close E, Gidron Y, Moss-Morris R (2008) Psychological distress and its correlates in ovarian cancer: a systematic review. Psychooncology 17(11): $1061-1072$

6 Armes J, Chalder T, Addington-Hall J, Richardson A, Hotopf $M$ (2007) A randomized controlled trial to evaluate the effectiveness of a brief, behaviorally oriented intervention for cancer-related fatigue. Cancer 110(6): 1385-1395

7 Arndt V, Stegmaier C, Ziegler H, Brenner H (2006) A population-based study of the impact of specific symptoms on quality of life in women with breast cancer 1 year after diagnosis. Cancer 107(10): 2496-2503

8 Avis NE, Deimling GT (2008) Cancer survivorship and aging. Cancer 113(12 Suppl): 3519-3529

9 Bae JM, Kim S, Kim YW, Ryu KW, Lee JH, Noh JH, Sohn TS, Hong SK, Park SM, You CH, Kim JH, Lee MK, Yun YH (2006) Health-related quality of life among disease-free stomach cancer survivors in Korea. Qual Life Res 15(10): 1587-1596

10 Bakitas M, Doyle Lyons KD, Hegel MT, Balan S, Brokaw FC, Seville J, Hull JG, Zhongze L, Tostetson TD, Byock IR, Ahles TA (2009) Effects of a palliative care intervention on clinical outcomes in patients with advanced cancer. The Project ENABLE II randomized controlled trial. JAMA 302(7): $741-749$

11 Bardia A, Barton DL, Prokop LJ, Bauer BA, Moynihan TJ (2006) Efficacy of complementary and alternative medicine therapies in relieving cancer pain: a systematic review. J Clin Oncol 24(34): 5457-5464

12 Barsevick AM, Sweeney C, Haney E, Chung E (2002) A systematic qualitative analysis of psychoeducational interventions for depression in patients with cancer. Oncol Nurs Forum 29: $73-84$

13 Beesley V, Eakin E, Steginga S, Aitken J, Dunn J, Battistutta D (2008) Unmet needs of gynaecological cancer survivors: implications for developing community support services. Psychooncology 17: $392-400$

14 Beesley V, Janda M, Eakin E, Obermair A, Battistutta D (2007) Lymphedema after gynecological cancer treatment: preva- lence, correlates, and supportive care needs. Cancer 109(12): $2607-2614$

15 Bellizzi KM, Blank TO (2006) Predicting posttraumatic growth in breast cancer survivors. Health Psychol 25: 47-56

16 Bettencourt B, Schlegel RJ, Talley AE, Molix LA (2007) The breast cancer experience of rural women: a literature review. Psychooncology 16(10): 875-887

17 Bloom JR, Petersen DM, Kang SH (2007) Multi-dimensional quality of life among long-term $(5+$ years $)$ adult cancer survivors. Psychooncology 16(8): 691-706

18 Bottomley A (1997) Where are we now: evaluating two decades of group interventions with adult cancer patients. J Psychiatr Ment Health Nurs 4 (4): $251-265$

19 Bowen DJ, Alfano CM, McGregor BA, Kuniyuki A, Bernstein L, Meeske K, Baumgartner KB, Fetherolf J, Reeve BB, Smith AW, Ganz PA, McTiernan A, Barbash RB (2007) Possible socioeconomic and ethnic disparities in quality of life in a cohort of breast cancer survivors. Breast Cancer Res Treat 106(1): 85-95

20 Bradley CJ, Oberst K, Schenk M (2006) Absenteeism from work: the experience of employed breast and prostate cancer patients in the months following diagnosis. Psychooncology 15(8): $739-747$

21 Brothers BM, Andersen BL (2009) Hopelessness as a predictor of depressive symptoms for breast cancer patients coping with recurrence. Psychooncology 18: 267-275

22 Bruera E, El Osta B, Valero V, Driver LC, Pei BL, Shen L, Poulter VA, Palmer JL (2007) Donepezil for cancer fatigue: a double-blind, randomized, placebo-controlled trial. J Clin Oncol 25(23): 3475-3481

23 Campbell HS, Phaneuf MR, Deane K (2004) Cancer peer support programs: do they work? Patient Educ Couns 55: $3-15$

24 Carlsen K, Dalton SO, Diderichsen F, Johansen C (2008) Risk for unemployment of cancer survivors: a Danish cohort study. Eur J Cancer 44(13): 1866-1874

25 Carr D, Goudas L, Lawrence D, Pirl W, Lau J, DeVine D, Kupelnick B, Miller K (2002) Management of cancer symptoms: pain, depression, and fatigue. Agency for Healthcare Research and Quality 61: 279

26 Challapalli V, Tremont-Lukats IW, McNicol ED, Lau J, Carr DB (2005) Systemic administration of local anesthetic agents to relieve neuropathic pain. Cochrane Database Syst Rev Issue 4. CD003345.

27 Clough-Gorr KM, Ganz PA, Silliman RA (2007) Older breast cancer survivors: factors associated with change in emotional well-being. J Clin Oncol 25: 1334-1340

28 Collins RF, Bekker HL, Dodwell DJ (2004) Follow-up care of patients treated for breast cancer: a structured review. Cancer Treat Rev 30: 19-35

29 Cooke B, Ernst E (2000) Aromatherapy: a systematic review. Br J Gen Pract 50: $493-496$

30 Costanzo ES, Ryff CD, Singer BH (2009) Psychosocial adjustment among cancer survivors: findings from a national survey of health and well-being. Health Psychol 28: $147-156$

31 Courneya KS, Segal RJ, Mackey JR, Gelmon K, Reid RD, Friedenreich CM, Ladha AB, Proulx C, Vallance JKH, Lane K, Yasui Y, McKenzie DC (2007) Effects of aerobic and resistance exercise in breast cancer patients receiving adjuvant chemotherapy: a multicenter randomized controlled trial. J Clin Oncol 25(28): 4396-4404

32 Cramp F, Daniel J (2008) Exercise for the management of cancer-related fatigue in adults. Cochrane Database Syst Rev Issue 2. CD006145.

33 Dahl AA, Bremnes R, Dahl O, Klepp O, Wist E, Fossa SD (2007) Is the sexual function compromised in long-term testicular cancer survivors? Eur Urol 52(5): 1438-1447 
34 Dahl AA, Haaland CF, Mykletun A, Bremnes R, Dahl O, Klepp O, Wist E, Fosså SD (2005) Study of anxiety disorder and depression in long-term survivors of testicular cancer. J Clin Oncol 23: 2389-2396

35 Daley AJ, Crank H, Saxton JM, Mutrie N, Coleman R, Roalfe A (2007) Randomized trial of exercise therapy in women treated for breast cancer. J Clin Oncol 25(13): 1713-1721

36 De Boer AGEM, Taskila T, Ojajarvi A, van Dijk FJH, Verbeek JHAM (2009) Cancer survivors and unemployment: a metaanalysis and meta-regression. JAMA 301(7): 753-762

37 De Boer AGEM, Verbeek JHAM, Spelten ER, Uitterhoeve ALJ, Ansink A, de Reijke TM, Kammeijer M, Sprangers MAG, van Dijk FJH (2008) Work ability and return-to-work in cancer patients. Br J Cancer 98(8): $1342-1347$

38 De Bruin ML, Burgers JA, Baas P, van't Veer MB, Noordijk EM, Louwman MWJ, Zijlstra JM, van den Berg H, Aleman BMP, van Leeuwen FE (2009) Malignant mesothelioma after radiation treatment for Hodgkin lymphoma. Blood 113(16): 3679-3681

39 Denton AS, Maher J (2003) Interventions for the physical aspects of sexual dysfunction in women following pelvic radiotherapy. Cochrane Database Syst Rev Issue 1. CD003750.

40 Edmondson D, Park CL, Blank TO, Fenster JR, Mills MA (2008) Deconstructing spiritual well-being: existential wellbeing and HRQOL in cancer survivors. Psychooncology 17: $161-169$

41 Edwards AGK, Hulbert-Williams N, Neal RD (2008) Psychological interventions for women with metastatic breast cancer. Cochrane Database Syst Rev Issue 3. CD004253.

42 Elkins G, Marcus J, Stearns V, Perfect M, Rajab MH, Ruud C, Palamara L, Keith T (2008) Randomized trial of a hypnosis intervention for treatment of hot flashes among breast cancer survivors. J Clin Oncol 26(31): 5022-5026

43 Ell K, Xie B, Quon B, Quinn DI, Dwight-Johnson M, Lee PJ (2008) Randomized controlled trial of collaborative care management of depression among low-income patients with cancer. J Clin Oncol 26(27): 4488-4496

44 Espie CA, Fleming L, Cassidy J, Samuel L, Taylor LM, White CA, Douglas NJ, Engleman HM, Kelly HL, Paul J (2008) Randomized controlled clinical effectiveness trial of cognitive behavior therapy compared with treatment as usual for persistent insomnia in patients with cancer. J Clin Oncol 26(28): $4651-4658$

45 Eton DT, Lepore SJ (2002) Prostate cancer and health-related quality of life: a review of the literature. Psychooncology 11(4): 307-326

46 Ezzo J, Richardson MA, Vickers A, Allen C, Dibble S, Issell BF, Lao L, Pearl M, Ramirez G, Roscoe JA, Shen J, Shivnan JC, Streitberger K, Treish I, Zhang G (2006) Acupuncture-point stimulation for chemotherapy-induced nausea or vomiting. Cochrane Database Syst Rev Issue 2. CD002285.

47 Falagas ME, Zarkadoulia EA, Ioannidou EN, Peppas G, Christodoulou C, Rafailidis PI (2007) The effect of psychosocial factors on breast cancer outcome: a systematic review. Breast Cancer Res 9(R44)

48 Fleer J, Hoekstra HJ, Sleijfer DT, Hoekstra-Weebers JE (2004) Quality of life of survivors of testicular germ cell cancer: a review of the literature. Support Care Cancer 12(7): $476-486$

49 Flynn P, Kew F, Kisely SR (2009) Interventions for psychosexual dysfunction in women treated for gynaecological malignancy. Cochrane Database Syst Rev Issue 2. CD004708.

50 Foley KL, Farmer DF, Petronis VM, Smith RG, Mcgraw S, Smith K, Carver CS, Avis N (2006) A qualitative exploration of the cancer experience among long-term survivors: comparisons by cancer type, ethnicity, gender, and age. Psychooncology 15: $248-258$
51 Foster C, Wright D, Hill H, Hopkinson J, Roffe L (2009) Psychosocial implications of living 5 years or more following a cancer diagnosis: a systematic review of the research evidence. Eur J Cancer Care 18(3): 223-247

52 Friedenreich CM, Courneya KS (1996) Exercise as rehabilitation for cancer patients. Clin J Sport Med 6(4): 237-244

53 Goedendorp MM, Gielissen MFM, Verhagen CAHHVM, Bleijenberg G (2009) Psychosocial interventions for reducing fatigue during cancer treatment in adults. Cochrane Database Syst Rev Issue 1. CD006953.

54 Goldzweig G, Andritsch E, Hubert A, Perry NWS, Brenner B, Baider L (2009) How relevant is marital status and gender variables in coping with colorectal cancer? A sample of middle-aged and older cancer survivors. Psychooncology 18: $866-874$

55 Goudas L, Carr DB, Bloch R, Balk E, Ioannidis JP, Terrin N, Gialeli-Goudas M, Chew P, Lau J (2001) Management of cancer pain. Volume 1. Volume 2: evidence tables. Agency for Healthcare Research and Quality

56 Greimel ER, Winter R, Kapp KS, Haas J (2009) Quality of life and sexual functioning after cervical cancer treatment: a longterm follow-up study. Psychooncology 18: 476-482

57 Grossman P, Deuring G, Garland SN, Campbell TS, Carlson LE (2008) Patterns of objective physical functioning and perception of mood and fatigue in posttreatment breast cancer patients and healthy controls: an ambulatory psychophysiological investigation. Psychosom Med 70(7): 819-828

58 Gysels M, Higginson IJ (2007) Interactive technologies and videotapes for patient education in cancer care: systematic review and meta-analysis of randomised trials. Support Care Cancer 15: 7-20

59 Harrison JD, Young JM, Price MA, Butow PN, Solomon MJ (2009) What are the unmet supportive care needs of people with cancer? A systematic review. Support Care Cancer 17(8): $1117-1128$

60 Haugnes HS, Aass N, Fossa SD, Dahl O, Brydoy M, Aasebo U, Wilsgaard T, Bremnes RM (2009) Pulmonary Function in Long-Term Survivors of Testicular Cancer. J Clin Oncol 27(17): $2779-2786$

61 Hayes SC, Janda M, Cornish B, Battistutta D, Newman B (2008) Lymphedema after breast cancer: Incidence, risk factors, and effect on upper body function. J Clin Oncol 26(21): $3536-3542$

62 Helgeson VS, Tomich PL (2005) Surviving Cancer: A comparison of 5-year disease-free breast cancer survivors with healthy women. Psychooncology 14: 307-317

63 Hodgkinson K, Butow P, Hobbs KM, Hunt GE, Lo SK, Wain G (2007) Assessing unmet supportive care needs in partners of cancer survivors: The development and evaluation of the Cancer Survivors' Partners Unmet Needs measure (CaSPUN). Psychooncology 16: 805-813

64 Hodgkinson K, Butow P, Hunt GE, Pendlebury S, Hobbs KM, Wain SKL, Wain G (2007) The development and evaluation of a measure to assess cancer survivors' unmet supportive care needs: The CaSUN (Cancer Survivors' Unmet Needs measure). Psychooncology 16: 796-804

65 Hormes JM, Lytle LA, Gross CR, Ahmed RL, Troxel AB, Schmitz KH (2008) The body image and relationships scale: development and validation of a measure of body image in female breast cancer survivors. J Clin Oncol 26: $1269-1274$

66 Horneber M, Bueschel G, Huber R, Linde K, Rostock M (2008) Mistletoe therapy in oncology. Cochrane Database Syst Rev Issue 2. CD003297.

67 Irajpour A, Norman I, Griffiths P (2006) Interprofessional education to improve pain management. Br J Commun Nurs 11(1): $29-32$ 
68 Jeffery M, Hickey BE, Hider PN (2007) Follow-up strategies for patients treated for non-metastatic colorectal cancer. Cochrane Database Syst Rev Issue 1. CD002200.

69 Jones RB, Pearson J, Cawsey AJ, Bental D, Barrett A, White J, White CA, Gilmour WH (2006) Effect of different forms of information produced for cancer patients on their use of the information, social support, and anxiety: randomised trial. BMJ 332(7547): 942 - 948

70 Jonker-Pool G, Van de Wiel HBM, Hoekstra HJ, Sleijfer DTh, Van Driel MF, Van Basten JP, Schraffordt Koops H (2001) Sexual functioning after treatment for testicular cancer: review and meta-analysis of 36 empirical studies between 1975-2000. Arch Sex Behav 30: 55-74

71 Kassab S, Cummings M, Berkovitz S, van Haselen R, Fisher P (2009) Homeopathic medicines for adverse effects of cancer treatments. Cochrane Database Syst Rev Issue 2. CD004845.

72 Kenny PM, King MT, Viney RC, Boyer MJ, Pollicino CA, McLean JM, Fulham MJ, McCaughan BC (2008) Quality of life and survival in the 2 years after surgery for non-small-cell lung cancer. J Clin Oncol 28: 233-241

73 Kirshbaum MN (2007) A review of the benefits of whole body exercise during and after treatment for breast cancer. J Clin Nurs 16: 104-121

74 Kiserud CE, Schover LR, Dahl AA, Fosså A, Bjøro T, Loge JH, Holte H, Yuan Y, Fosså SD (2009) Do male lymphoma survivors have impaired sexual function? J Clin Oncol. Published online ahead of print. DOI: 10.1200/JCO.2009.23.2280

75 Knols R, Aaronson NK, Uebelhart D, Fransen J, Aufdemkampe G (2005) Physical exercise in cancer patients during and after medical treatment: a systematic review of randomized and controlled clinical trials. J Clin Oncol 23: $3830-3842$

76 Kobayashi K, Morita S, Shimonagayoshi M, Kobayashi M, Fujiki Y, Uchida Y, Yamaguchi K (2008) Effects of socioeconomic factors and cancer survivors' worries on their quality of life (QOL) in Japan. Psychooncology 17: 606-611

77 Kornblith AB, Dowell JM, Herndon JE, Engelman BJ, BauerWu S, Small EJ, Morrison VA, Atkins J, Cohen HJ, Holland JC (2006) Telephone monitoring of distress in patients aged 65 years or older with advanced stage cancer: a cancer and leukemia group B study. Cancer 107(11): 2706-2714

78 Kornblith AB, Powell M, Regan MM, Bennett S, Krasner C, Moy B, Younger J, Goodman A, Berkowitz R, Winer E (2007) Long-term psychosocial adjustment of older $v s$ younger survivors of breast and endometrial cancer. Psychooncology 16: $895-903$

79 Krischer MM, Xu P, Meade CD, Jacobsen PB (2007) Selfadministered stress management training in patients undergoing radiotherapy. J Clin Oncol 25(29): 4657-4662

80 Krouse RS, Herrinton LJ, Grant M, Wendel CS, Green SB, Mohler MJ, Baldwin CM, McMullen CK, Rawl SM, Matayoshi E, Coons SJ, Hornbrook MC (2009) Health-related quality of life among long-term rectal cancer survivors with an ostomy: manifestations by sex. J Clin Oncol 27(28): $4664-4670$

81 Krupski TL, Kwan L, Fink A, Sonn GA, Maliski S, Litwin MS (2006) Spirituality influences health related quality of life in men with prostate cancer. Psychooncology 15: 121-131

82 Lee MK, Lee KM, Bae JM, Kim S, Kim YW, Ryu KW, Lee JH, Noh JH, Sohn TS, Hong SK, Yun YH (2008) Employment status and work-related difficulties in stomach cancer survivors compared with the general population. Br J Cancer 98(4): $708-715$

83 Leining MG, Gelber S, Rosenberg R, Przypyszny M, Winer EP, Partridge AH (2006) Menopausal-type symptoms in young breast cancer survivors. Ann Oncol 17(12): 1777-1782

84 Lockwood-Rayermann S (2006) Survivorship issues in ovarian cancer: a review. Oncol Nurs Forum 33(3): 553-562
85 Mansky P, Sannes T, Wallerstedt D, Ge A, Ryan M, Johnson LL, Chesney M, Gerber L (2006) Tai chi chuan: mind-body practice or exercise intervention? Studying the benefit for cancer survivors. Integr Cancer Ther 5: 192-201

86 Markes M, Brockow T, Resch K-L (2006) Exercise for women receiving adjuvant therapy for breast cancer. Cochrane Database Syst Rev Issue 4. CD005001.

87 Matei D, Miller AM, Monahan P, Gershenson D, Zhao QQ, Cella D, Champion VL, Williams SD (2009) Chronic physical effects and health care utilization in long-term ovarian germ cell tumor survivors: a gynecologic oncology group study. $J$ Clin Oncol 27(25): 4142-4149

88 McNeely ML, Parliament MB, Seikaly H, Jha N, Magee DJ, Haykowsky MJ, Courneya KS (2008) Effect of exercise on upper extremity pain and dysfunction in head and neck cancer survivors: a randomized controlled trial. Cancer 113(1): 214-222

89 McPherson CJ, Higginson IJ, Hearn J (2001) Effective methods of giving information in cancer: a systematic literature review of randomized controlled trials. J Pub Health Med 23: $227-234$

90 Miles C, Candy B, Jones L, Williams R, Tookman A, King M (2007) Interventions for sexual dysfunction following treatments for cancer. Cochrane Database Syst Rev Issue 4. CD005540.

91 Milne HM, Wallman KE, Gordon S, Courneya KS (2008) Effects of a combined aerobic and resistance exercise program in breast cancer survivors: a randomized controlled trial. Breast Cancer Res Treat 108(2): 279-288

92 Minton O, Stone P, Richardson A, Sharpe M, Hotopf M (2008) Drug therapy for the management of cancer related fatigue. Cochrane Database Syst Rev Issue 1. CD006704

93 Moadel AB, Shah C, Wylie-Rosett J, Harris MS, Patel SR, Hall CB, Sparano JA (2007) Randomized controlled trial of yoga among a multiethnic sample of breast cancer patients: effects on quality of life. J Clin Oncol 25(28): 4387-4395

94 Mols F, Korfage IJ, Vingerhoets AJJM, Kil PJM, Coebergh JWW, Essink-Bot ML, Van de Poll-Franse LV (2009) Bowel, urinary, and sexual problems among long-term prostate cancer survivors: a population-based study. Int J Radiat Oncol Biol Phys 73(1): 30-38

95 Mols F, Vingerhoets AJJM, Coebergh JW, Van De PollFranse LV (2005) Quality of life among long-term breast cancer survivors: a systematic review. Eur J Cancer 41(17): $2613-2619$

96 Morris ME, Grant M, Lynch JC (2007) Patient-reported family distress among long-term cancer survivors. Cancer Nurs 30(1): $1-8$

97 Neuhouser ML, Sorensen B, Hollis BW, Ambs A, Ulrich CM, McTiernan A, Bernstein L, Wayne S, Gilliland F, Baumgartner K, Baumgartner R, Ballard-Barbash R (2008) Vitamin D insufficiency in a multiethnic cohort of breast cancer survivors. Am J Clin Nutr 88(1): 133-139

98 Newell SA, Sanson-Fisher RW, Savolainen NJ (2002) Systematic review of psychological therapies for cancer patients: overview and recommendations for future research. $J$ Natl Cancer Inst 94: 558-584

99 Nicholson AB (2007) Methadone for cancer pain. Cochrane Database Syst Rev Issue 4. CD003971.

100 Northouse LL, Mood DW, Schafenacker A, Montie JE, Sandler HM, Forman JD, Hussain M, Pienta KJ, Smith DC, Kershaw T (2007) Randomized clinical trial of a family intervention for prostate cancer patients and their spouses. Cancer 110(12): $2809-2818$

101 Osborn RL, Demoncada AC, Feuerstein M (2006) Psychosocial interventions for depression, anxiety, and quality of life in cancer survivors: meta-analyses. Int J Psychiatry Med 36: $13-34$ 
102 Park CL, Gaffey AE (2007) Relationships between psychosocial factors and health behavior change in cancer survivors: an integrative review. Ann Behav Med 34(2): 115-134

103 Park SY, Bae DS, Nam JH, Park CT, Cho CH, Lee JM, Lee MK, Kim SH, Park SM, Yun YH (2007) Quality of life and sexual problems in disease-free survivors of cervical cancer compared with the general population. Cancer 110(12): 2716-2725

104 Parker PA, Pettaway CA, Babaian RJ, Pisters LL, Miles B, Fortier A, Wei Q, Carr DD, Cohen L (2009) The effects of a presurgical stress management intervention for men with prostate cancer undergoing radical prostatectomy. J Clin Oncol 27(19): 3169-3176

105 Paskett ED, Herndon II JE, Day JM, Stark NN, Winer EP, Grubbs SS, Pavy MD, Shapiro CL, List MA, Hensley ML, Naughton MA, Kornblith AB, Habin KR, Fleming GF, Bittoni MA (2008) Applying a conceptual model for examining health related quality of life in long-term breast cancer survivors: CALGB study 79804. Psychooncology 17: 1108-1120

106 Passalacqua R, Caminiti C, Campione F, Diodati F, Todeschini R, Bisagni G, Labianca R, Chiesa MD, Bracci R, Aragona M, Artioli F, Cavanna L, Masina A, De Falco F, Marzocchini B, Iacono C, Contu A, Costanzo FD, Bertetto O, Annunziata MA (2009) Prospective, multicenter, randomized trial of a new organizational modality for providing information and support to cancer patients. J Clin Oncol 27(11): 1794-1799

107 Petticrew M, Bell R, Hunter D (2002) Influence of psychological coping on survival and recurrence in people with cancer: Systematic review. BMJ 325(7372): 1066-1069

108 Peuckmann V, Ekholm O, Rasmussen NK, Groenvold M, Christiansen P, Moller S, Eriksen J, Sjogren P (2009) Chronic pain and other sequelae in long-term breast cancer survivors: Nationwide survey in Denmark. Eur J Pain 13(5): 478-485

109 Pitkethly M, MacGillivray S, Ryan R (2008) Recordings or summaries of consultations for people with cancer. Cochrane Database Syst Rev Issue 3. CD001539.

110 Quigley C (2002) Hydromorphone for acute and chronic pain. Cochrane Database Syst Rev Issue 1. CD003447.

111 Rao AV, Demark-Wahnefried W (2006) The older cancer survivor. Crit Rev Oncol Hematol 60(2): 131-143

112 Rehse B, Pukrop R (2003) Effects of psychosocial interventions on quality of life in adult cancer patients: meta analysis of 37 published controlled outcome studies. Patient Educ Couns 50: $179-186$

113 Richards KC, Gibson R, Overton-McCoy AL (2000) Effects of massage in acute and critical care. AACN Clinical Issues: Advanced Practice in Acute and Critical Care 11: 77-96

114 Robb KA, Bennett MI, Johnson MI, Simpson KJ, Oxberry SG (2008) Transcutaneous electric nerve stimulation (TENS) for cancer pain in adults. Cochrane Database Syst Rev Issue 3. CD006276.

115 Rodin G, Lloyd G, Katz M, Green E, Mackay JA, Wong RK (2007) The treatment of depression in cancer patients: a systematic review. Support Care Cancer 15: 123-136

116 Roscoe JA, Kaufman ME, Matteson-Rusby SE, Palesh OG, Ryan JL, Kohli S, Perlis ML, Morrow GR (2007) Cancerrelated fatigue and sleep disorders. Oncologist 12: 35-42

117 Rossen PB, Pedersen A, Zachariae R, von der Maase H (2009) Health-related quality of life in long-term survivors of testicular cancer. J Clin Oncol. Published ahead of print. DOI:10.1200/JCO.2008.19.6931

118 Russell KM, Von Ah DM, Giesler RB, Storniolo AM, Haase JE (2008) Quality of life of African American breast cancer survivors: how much do we know? Cancer Nurs 31(6): E36-E45

119 Salsman JM, Segerstrom SC, Brechting EH, Carlson CR, Andrykowski MA (2009) Posttraumatic growth and PTSD symptomatology among colorectal cancer survivors: a 3-month longitudinal examination of cognitive processing. Psychooncology 18: 30-41

120 Saquib N, Flatt SW, Natarajan L, Thomson CA, Bardwell WA, Caan B, Rock CL, Pierce JP (2007) Weight gain and recovery of pre-cancer weight after breast cancer treatments: evidence from the women's healthy eating and living (WHEL) study. Breast Cancer Res Treat 105(2): 177-186

121 Schneider EC, Malin JL, Kahn KL, Ko CY, Adams J, Epstein AM (2007) Surviving colorectal cancer: patient-reported symptoms 4 years after diagnosis. Cancer 110(9): 2075-2082

122 Sellick SM, Zaza C (1998) Critical review of 5 nonpharmacologic strategies for managing cancer pain. Cancer Prevent Control 2: 7-14

123 Servaes P, Verhagen C, Bleijenberg G (2002) Fatigue in cancer patients during and after treatment: prevalence, correlates and interventions. Eur J Cancer 38(1): 27-43

124 Sheard T, Maguire P (1999) The effect of psychological interventions on anxiety and depression in cancer patients: results of two meta analyses. $\mathrm{Br}$ J Cancer 80(11): 1770-1780

125 Short PF, Vasey JJ, Belue R (2008) Work disability associated with cancer survivorship and other chronic conditions. Psychooncology 17(1): 91-97

126 Skaali T, Fossa SD, Bremnes R, Dahl O, Haaland CF, Rønneberg Hauge E, Olbjør n Klepp, Oldenburg J, Wist E, Dahl AA (2009) Fear of recurrence in long-term testicular cancer survivors. Psychooncology 18: 580-588

127 Smedslund G, Ringdal GI (2004) Meta-analysis of the effects of psychosocial interventions on survival time in cancer patients. J Psychosom Res 57(2): 123-131

128 Smith JE, Richardson J, Hoffman C, Pilkington K (2005) Mindfulness-based stress reduction as supportive therapy in cancer care: systematic review. J Adv Nurs 52(3): 315-327

129 Smith SK, Zimmerman S, Williams CS, Preisser JS, Clipp EC (2008) Post-traumatic stress outcomes in non-Hodgkin's lymphoma survivors. J Clin Oncol 28: 934-941

130 Solà I, Thompson EM, Subirana Casacuberta M, Lopez C, Pascual A (2004) Non-invasive interventions for improving well-being and quality of life in patients with lung cancer. Cochrane Database Syst Rev Issue 4. CD004282.

131 Somani BK, Kumar V, Wong S, Pickard R, Ramsay C, Nabi G, Grant A, N'Dow J (2007) Bowel dysfunction after transposition of intestinal segments into the urinary tract: 8-year prospective cohort study. J Urol 177(5): 1793-1798

132 Spelten E, Sprangers M, Verbeek J (2002) Factors reported to influence the return to work of cancer survivors: a literature review. Psychooncology 11(2): 31

133 Steginga SK, Lynch BM, Hawkes A, Dunn J, Aitken J (2009) Antecedents of domain-specific quality of life after colorectal cancer. Psychooncology 18: 216-220

134 Strong V, Waters R, Hibberd C, Murray G, Wall L, Walker J, McHugh G, Walker A, Sharpe M (2008) Management of depression for people with cancer (SMaRT oncology 1): a randomised trial. Lancet 372(9632): $40-48$

135 Syrjala KL, Abrams JR, Polissar NL, Hansberry J, Robison J, DuPen S, Stillman M, Fredrickson M, Rivkin S, Feldman E, Gralow J, Rieke JW, Raish RJ, Lee DJ, Cleeland CS, DuPen A (2008) Patient training in cancer pain management using integrated print and video materials: a multisite randomized controlled trial. Pain 135(1-2): 175-186

136 Taskila T, Martikainen R, Hietanen P, Lindbohm ML (2007) Comparative study of work ability between cancer survivors and their referents. Eur J Cancer 43(5): 914-920

137 Tatrow K, Montgomery GH (2006) Cognitive behavioral therapy techniques for distress and pain in breast cancer patients: a meta-analysis. J Behav Med 29: 17-27

138 Thornton AA, Perez MA (2006) Posttraumatic growth in prostate cancer survivors and their partners. Psychooncology 15: $285-296$ 
139 Vallance JKH, Courneya KS, Plotnikoff RC, Yasui Y, Mackey JR (2007) Randomized controlled trial of the effects of print materials and step pedometers on physical activity and quality of life in breast cancer survivors. J Clin Oncol 25(17): $2352-2359$

140 Van den Beuken-van Everdingen MHJ, Peters ML, De Rijke JM, Schouten HC, Van Kleef M, Patijn J (2008) Concerns of former breast cancer patients about disease recurrence: a validation and prevalence study. Psychooncology 17: $1137-1145$

141 Visovsky C, Schneider SM (2003) Cancer-related fatigue. Online J Issues Nurs 8(3): 8

142 Vivar CG, Canga N, Canga AD, Arantzamendi M (2009) The psychosocial impact of recurrence on cancer survivors and family members: a narrative review. J Adv Nurs 65(4): $724-736$

143 Vivar CG, McQueen A (2005) Informational and emotional needs of long-term survivors of breast cancer. J Adv Nurs 51(5): $520-528$

144 Walsh RA, Girgis A, Sanson-Fisher RW (1998) Breaking bad news 2: what evidence is available to guide clinicians? Behav Med 24(2): $61-72$

145 Weathers B, Barg FK, Collier A, Halbert CH (2006) Perceptions of changes in weight among African American breast cancer survivors. Psychooncology 15(2): 174-179

146 Weber BA, Sherwill-Navarro P (2005) Psychosocial consequences of prostate cancer: 30 years of research. Geriatr Nurs 26(3): $166-175$

147 Wessex Institute for Health Research and Development (1998). Psycho-social interventions in oncology: counselling services for women with breast cancer. Southampton: Wessex
Institute for Health Research and Development. Development and Evaluation Committee Report; 86

148 Wiffen PJ, McQuay HJ (2007) Oral morphine for cancer pain. Cochrane Database Syst Rev Issue 4. CD003868.

149 Wilkinson SM, Love SB, Westcombe AM, Gambles MA, Burgess CC, Cargill A, Young T, Maher EJ, Ramirez AJ (2007) Effectiveness of aromatherapy massage in the management of anxiety and depression in patients with cancer: a multicenter randomized controlled trial. J Clin Oncol 25(5): $532-539$

150 Williams S, Dale J (2006) The effectiveness of treatment for depression/depressive symptoms in adults with cancer: a systematic review. Br J Cancer 94(3): 372-390

151 Wootten AC, Burney S, Foroudi F, Frydenberg M, Coleman G, $\mathrm{Ng}$ KT (2007) Psychological adjustment of survivors of localised prostate cancer: investigating the role of dyadic adjustment, cognitive appraisal and coping style. Psychooncology 16: $994-1002$

152 Zabalegui A, Sanchez S, Sanchez PD, Juando C (2005) Nursing and cancer support groups. J Adv Nurs 51(4): 369-381

153 Zebrack BJ, Yi J, Petersen L, Ganz PA (2008) The impact of cancer and quality of life for long-term survivors. Psychooncology 17: 891-900

154 Zeppetella G, Ribeiro MDC (2006) Opioids for the management of breakthrough (episodic) pain in cancer patients. Cochrane Database Syst Rev Issue 1. CD004311.

cc)(7) (ㄱ) This work is licensed under the Creative Commons cc. BY NC SA Attribution-NonCommercial-Share Alike 3.0 Unported License. To view a copy of this license, visit http://creativecommons. org/licenses/by-nc-sa/3.0/ 